loss for addresses and sources of information. To meet this need, the Association of Special Libraries and Information Bureaux has issued "ASLIB Guide to British Sources of Specialised Information. No. 1, Fuel and Allied Industries (excluding Electricity)" (2s. 6d. to non-members. ASLIB, 31 Museum Street, London, W.C.1). It indicates what new organizations have arisen and what modifications have been made in war-time. Particulars are given of relevant Government and other departments, professional, trade, and research organizations, university teaching departments and libraries, commercial and industrial organizations, periodicals printing abstracts and references, trade periodicals, periodicals issued by professional bodies and industrial concerns, and annuals. The list is comprehensive, and a perusal failed to note the omission of any address or paper concerned with fuels in war-time. It should find a useful place on the table of everyone concerned with administration or investigation of fuel affairs in these times.

\section{William Withering and Erasmus Darwin}

The June issue of the Bulletin of the History of Medicine contains an interesting notice by Drs. Ruth Musser and John C. Krantz, jun., on the friendship of William Withering and Erasmus Darwin. In 1775, nine years after graduating as M.D. at Edinburgh, Withering, who was in practice at Birmingham, became intimately associated with Erasmus Darwin, an Edinburgh doctor of medicine ten years his senior, and was admitted by him to the Lunar Society which Darwin and others had founded. The outstanding members of this Society were James Watt, Joseph Priestley and Josiah Wedgwood, and the visitors included among others Herschel and Benjamin Franklin. The friendship of Darwin and Withering continued for many years. Each enjoyed a wide reputation and an extensive practice. The greatest contribution which Withering made to posterity was his use of the purple foxglove in the treatment of dropsy, the description of which is to be found in his classical work published in 1785 entitled "The Foxglove, an Account of its Medical Properties", while of Darwin it has been said that there was scarcely an invention in the world to-day that his mind did not foresee. Withering died in 1799 at the relatively early age of fifty-three, but Darwin survived until 1802 , or seven years before the birth of his grandson, the author of "The Origin of Species".

\section{The Newcomen Society}

The Newcomen Society has recently published vol. 19 of its Transactions, its sixth Quarterly Bulletin and its programme of papers for the session 1940-41. Seven meetings have been arranged, and the papers to be presented deal with the history of many subjects, among these being the sugar-cane industry, the iron industry, Henry Corte's bicentenary, the Surrey iron railway, needle-making, wire and plate gauges and the hydraulic extrusion of metals. In the Quarterly Bulletin, reference is made to the movement in the United States to preserve the birthplace of Robert Fulton, and to the erection of a tablet on a granite shaft over the burial place of Oliver Evans, in Trinity Churchyard, Broadway, New York. The 'pilgrimage' of members of the Society in America which was to have taken place in New Hampshire in June was abandoned on the receipt of the news of the defeat of France.

The new volume of the Transactions contains thirteen papers and nine other communications, together with a continuation of the valuable analytical bibliography of the history of engineering The volume runs to 290 pages and contains twenty-four plates. Most of the papers were referred to in our columns at the time they were read. Among the notes and communications is a list of 320 engineering drawings dating from 1775 to 1840 preserved at the Science Museum in the Goodrich Collection, and a description of the first dry dock in the Netherlands (1707) by Lieut. J. J. Bootsgezel, of the Netherland Royal Navy, who, it has been learnt, lost his life through a mine when escaping from Holland. $\mathrm{He}_{\mathrm{e}}$ was well known for his great interest in the records of Dutch engineering. The president of the Society for the current year is Col. C. E. Davies, secretary of the American Society of Mechanical Engineers; his address will be read in both New York and London on November 13.

\section{Electromagnetic Levitation}

Av exhibit which has proved attractive at the Centennial Exhibition of the Dominion of New Zealand is showing an aluminium plate floating in air in a strong alternating-current field and frying eggs in a pan without visible means of heating and support. An iron core is concealed beneath a table top and excited by A.c. windings so arranged and connected that they produce alternating magnetic fields, toroidal in form, of high intensity and opposite polarity. An aluminium pan floats on this field with such definition of position that considerable effort is required to move it downwards or sideways. Heat generated in the pan, by currents induced by the field, does the cooking. It is very suitable as an exhibit for publicity purposes, but at present it does not look as if it has any practical application, as a very large electrical input is required to maintain a magnetic field of suitable form and intensity.

\section{Seismological Data from India}

MUCH useful seismological data is contained in the Seismological Bulletin of April, May and June, 1939, recently published by the Government of India Meteorological Department. It contains interpretations of the seismograms obtained at seven observatories in India and Ceylon together with macroseismic data supplied by voluntary observers in nine regions. About sixty earthquakes were recorded at each of the observatories for the three months, though only nineteen were registered at the Haig Observatory at Dehra Dun. This is not considered significant on account of the types of instruments in use at the stations, a full list of which is given. The region near Shillong appears to have experienced more earthquakes than any other during the period, having had 
five on four separate days. The most intense activity, however, seems to have been near Silchar on May 27, 1939, when eight shocks were felt attaining a maximum intensity seven on the Rossi-Forel scale (overturning of loose objects ; fall of plaster ; general fright, though no damage to property). The total duration of shaking was approximately $3 \frac{1}{2}$ minutes.

\section{Undulant Fever in Normandy}

IN his inaugural thesis (Thèse de Paris, 1940, No. 322), Dr. M. L. Rose-Legrand remarks that until the last few years the five departments of Normandy were regarded as free from human undulant fever. Recent publications, however, indicate that Normandy has by no means escaped visitations of this disease, as is shown by the fact that the writer has been able to collect at least twenty-seven cases in the course of the last six years, eleven being in SeineInférieure, six in Calvados, five in Eure, three in Manche and one in Orne. With the exception of a single case caused by $B$. melitensis, all the cases of human undulant fever have resulted from infection by $B$. abortus bovis. Not a single case in the departments of Normandy has been due to goats or sheep. In two instances infection was caused by accidental inoculation, namely, by a polyvalent vaccine in a veterinary surgeon, and in another in a cattle breeder. In the majority of cases inoculation has taken place through the skin and only in a minority by consump. tion of raw milk from infected cows. Hitherto, there have been no instances of human infection by cheese. In conclusion, the writer recommends that the wellestablished existence of undulant fever in Normandy should receive the attention of veterinary and medical practitioners, especially in rural districts. In another thesis (Thèse de Paris, 1940, No. 277), Dr. R. G. C. F. Grigny states that he has recently collected ten cases of undulant fever which have occurred during the last four years in the department of the Somme, where contagious abortion has recently been frequent among the cattle.

\section{Carnegie Institution of Washington}

YEAR BooK No. 38 of the Carnegie Institution of Washington has been issued and covers the year July 1, 1938-June 30, 1939. It includes the report of the President, the reports of the various Departments, including the Mount Wilson Observatory, the Geophysical Laboratory, the Department of Terrestrial Magnetism, the Division of Plant Biology, the Division of Animal Biology and the Division of Historical Research, as well as reports on investigations by research associates and on special co-operative studies such as those of the committee on co-ordination of cosmic ray investigations. The astronomical staff at Mount Wilson has continued to co-operate with the physicists and engineers of the Californian Institute of Technology in the construction of the 200-inch telescope with the aid of funds furnished by the Rockefeller Foundation.

The Department of Terrestrial Magnetism, in co-operation with George Washington University, held a conference on theoretical physics in the spring, and keen interest was also taken in a similar conference on the ionosphere. Special reference is made in the report to the work of the Division of Plant Biology on photosynthesis, including studies of the quantum efficiency of photosynthesis. The work of the Division of Animal Biology has included biochemical studies of secretion, the physiology of reproduction, endocrine studies, studies of the central nervous system, as well as investigations on the chromosome and the gene. Research activities in the Nutrition Laboratory have centred largely around the factors governing heat regulation and heat production in animals and human beings.

\section{A Guide to Farming}

THE fifteenth issue of the "Farmer's Guide" has been published in the Journal of the Royal Agricultural Society of England, 101, Part 1. It follows the lines of former issues, but naturally a good deal of the work under review bears on the special problems of war-time farming. The contributors to the various sections are the same as last year, except that Prof. T. Dalling has replaced Dr. F. C. Minett as the writer on animal diseases. In future the Journal will be issued in two parts only, at half-yearly intervals, instead of in three parts as originally planned. So far as can be foreseen at present, Part 2 of the current volume will be published in March 1941.

\section{Announcements}

IN connexion with Dr. R. Melville's letter on p. 403 of this issue, it may be noted that the Board of Education has issued a memorandum suggesting the collection by school children of wool, dandelion roots, autumn crocus roots and seeds, acorns and beech mast, and horse chestnuts.

Dr. Ivor JENNING has been appointed principal of the University College of Ceylon, and Mr. Stanley A. A. Hammond educational adviser on the West Indian Comptroller's staff.

According to Science, Dr. Bruno Gerhard, formerly curator of the Museum of Hygiene in Dresden, has been appointed director of the Cleveland Museum of Health and Hygiene, which will open in October. Since 1937, Dr. Gerhard has been serving as technical consultant for the medicine and public health exhibits at the World's Fair in New York. Plans for the Cleveland Museum were initiated in 1939 when Mrs. Francis F. Prentișs gave the building. In addition to exhibits for education in public health, the museum expects to have workshops for the creation of visual health aids for schools, colleges and other educational institutions.

Dr. Joseph NeenhaM has pointed out that a misprint appears in the title of an article by him in association with Dr. A. S. C. Lawrence and Dr. Shih-Chang Shen in Nature of July 20, p. 104. The full title of the original paper was "Studies on Protein Solutions with the Co-axial (or Couette) Viscosimeter, with reference to the Relations between Molecular and Morphological Shape" ; this would of course have been too cumbersome for an article in NATURE. 